\title{
PROSES PELAYANAN SOSIAL DI RUMAH YATIM AT-TAMIM KECAMATAN CILEUNYI KABUPATEN BANDUNG
}

\author{
Oleh: \\ Eni Setiyawati, Santoso Tri Raharjo, \& Muhammad Fedryansyah \\ Email: \\ enisetiyaa@gmail.com; santosotriraharjo@yahoo.com; fedry_cons@yahoo.com
}

\begin{abstract}
The presence of human services organiation in Indonesia which was established by the private sector is one of the alternatives in answering the problems of meeting the needs of children and other children's rights because the government has not been able to solve the problems related to social services for children overall. Over the years many home-based social service agencies or religion stands in Indonesia, especially Bandung regency. One of them is the Rumah Yatim At-Tamim, which provide social services in support of the fulfillment of children's rights in order to achieve the welfare of children, including child care in meeting the needs of everyday life, both primary needs and other needs that support and should be maximized. This research uses descriptive method with qualitative approach. To obtain the necessary data, the researchers used a technique-depth interviews, direct observations in the field, and documentation study. Another form of services such as protection, child development, education and health also needs to be considered so children can run their social functioning properly. This will be supported if social service agencies capable of carrying out the process of social services with well too.
\end{abstract}

Keywords: Human services organization, Rumah Yatim At-Tamim, social services for children, fullfilment need based, the process of social services.

\section{ABSTRAK}

Hadirnya lembaga pelayanan sosial berbasis panti di Indonesia yang didirikan oleh swasta merupakan salah satu alternatif dalam menjawab permasalahan pemenuhan kebutuhan anak dan hak anak lainnya karena pemerintah belum mampu dalam menuntaskan permasalahan yang berkaitan dengan pelayanan sosial bagi anak secara keseluruhan. Dari tahun ke tahun banyak lembaga pelayanan sosial berbasis panti atau pun agama berdiri di Indonesia, khususnya kabupaten Bandung. Salah satunya adalah Rumah Yatim At-Tamim yang memberikan pelayanan sosial dalam mendukung pemenuhan hak anak agar dapat tercapai kesejahteraan anak, termasuk pelayanan dalam memenuhi kebutuhan anak sehari-hari, baik kebutuhan primer maupun kebutuhan lain yang mendukung dan harus dimaksimalkan. Penelitian ini menggunakan metode deskriptif dengan pendekatan kualitatif. Untuk memperoleh data yang diperlukan, peneliti menggunakan teknik wawancara mendalam, observasi langsung di lapangan, dan studi dokumentasi. Bentuk pelayanan lain seperti perlindungan, perkembangan anak, mendapatkan pendidikan dan kesehatan pun perlu untuk dipertimbangkan sehimgga anak dapat menjalankan keberfungsian sosialnya dengan baik. Hal ini pun akan didukung jika lembaga pelayanan sosial mampu menjalankan proses pelayanan sosial dengan baik pula.

Kata Kunci : Lembaga pelayanan sosial, Rumah Yatim At-Tamim, pelayanan sosial bagi anak, pemenuhan kebutuhan dasar, proses pelayanan sosial. 


\section{PENDAHULUAN}

Di kabupaten Bandung khususnya kecamatan Cileunyi terdapat 16 yayasan yang berdiri dan bergerak dalam bidang sosial, keagaamaan dan pendidikan termasuk Rumah Yatim At-Tamim (http://www.bandungkab.go.id/ uploads/ DATA_YAYASAN_KESBANG.pdf).

Lebih lanjut berdasarkan penelitian yang dilakukan Save The Children , UNICEF dan Kementrian Sosial Republik Indonesia pada tahun 2007 (perlu diperbaharui) terdapat 50008000 lembaga pengasuhan alternatif di Indonesia dalam bentuk panti asuhan anak. Penyelenggaraan panti asuhan ini mayoritas dimiliki oleh masyarakat sebesar $99 \%$ dan hanya 40 panti asuhan anak yang dimiliki oleh pemerintah. Anak anak ditempatkan di panti asuhan berdasarkan atas alasan kemiskinan yakni sebesar $90 \%$ dan karena alasan yatim piatu sebesar $6 \%$. Kualitas panti asuhan yang masih sangat rendah, rasio perbandingan pengasuh dengan anak yang diasuh tidak seimbang, kualitas pengasuh panti tidak sesuai dengan standar, bahkan terdapat kasus kekerasan di dalam panti, sarana dan prasarana yang terbatas menyebabkan anak tidak dalam situasi yang lebih baik berada di dalam panti.

Rumah Yatim At-Tamim merupakan salah satu lembaga pelayanan sosial (human service organization) semi panti yang berbasis agama Islam dan memberikan layanan sosial bagi anak yatim, dhuafa dan muallaf. Rumah Yatim At-Tamim memiliki tujuan untuk memberi bantuan kepada siapapun yang membutuhkan dan memenuhi kebutuhan anak termasuk pendidikan agar dapat berkembang tentunya sesuai dengan prinsip agama Islam. Rumah Yatim At-Tamim ini juga menampung anak dari berbagai latar belakang yang berbeda, bermacam karakteristik, usia, dan jenis kelamin. Berada dibawah naungan pondok pesantren, Rumah Yatim At-Tamim dan sudah berdiri selama 10 tahun dan kini Rumah Yatim At-Tamim menampung kurang lebih 55 orang anak yatim, dhuafa maupun muallaf yang terdiri dari santri ikhwan dan akhwat yang masih berstatus pelajar mulai dari kelas 3 SD, SMP, SMA hingga kuliah.

Hal yang menarik dan unik ketika lembaga pelayanan sosial ini menampung anak anak dari luar pulau Jawa, yaitu wilayah timur utamanya dari NTT. Rumah Yatim At-Tamim juga memberikan layanan sosial berupa tempat tinggal, pemenuhan kebutuhan primer (makan dan minum), pelayanan dalam bidang pendidikan baik secara formal maupun informal dengan memberikan uang saku dan memenuhi kebutuhan santri sehari-hari, penyediaan sarana dan prasarana dalam mendukung pendidikan, pemberian tambahan belajar agama Islam dan pendidikan keterampilan. Melihat fenomena tersebut, maka isu pelayanan sosial di lembaga pelayanan sosial yang berbasis agama ini penting untuk diteliti karena kita sebagai pekerja sosial yang berada dalam setting human service organization memiliki peran dalam memberikan layanan sosial khususnya dalam lembaga pelayanan sosial.

Beberapa penelitian sebelumnya yang mengulas pelayanan sosial oleh lembaga pelayanan sosial diantaranya oleh Rossy Simarmata (2013) dengan judul “ Efektivitas Pelayanan Sosial Terhadap Anak Asuh oleh Yayasan Kinderfreude" meneliti tentang efektivitas pelayanan yang diberikan oleh lembaga seperti pendidikan, keterampilan, bimbingan dan kesehatan terhadap anak asuh belum secara detail mengungkap pelayanan dari sisi yayasan Kinderfreude yang memiliki basis agama yang memiliki nilai lebih. Selain itu, proses yang ditampilkan masih di dominasi oleh out put yang dihasilkan dari program yang bersangkutan. Penelitian selanjutnya oleh Hariana (2013) berjudul "Efektivitas Pelayanan Sosial Anak di Bidang Pendidikan Oleh Panti Asuhan Yayasan Amal Sosial AlWashliyah Kelurahan Gedung Johor Kecamatan Medan Johor" belum secara detail menggambarkan bidang pelayanan pendidikan yang diselenggarakan, terutama program yang 
bersangkutan dengan pendidikan. Selain itu, masih terdapat paparan yang mengaitkan dengan pola pengasuhan anak di Yayasan tersebut, sedangkan peneliti ingin meneliti prosesnya sebagai bagian yang penting dalam pemberian layanan sosial.

Penelitian selanjutnya mengenai "Kondisi Psikososial Anak yang Dibesarkan di Panti Asuhan" oleh Karolina Lamtiur Dalimunthe (2009) lebih banyak memberi saran agar anak tidak dimasukkan ke dalam panti. Peneliti juga banyak mengungkapkan teori-teori yang mendukung dalam menjelaskan dampak negatif pengasuhan di panti terhadap psikososial anak tetapi hal ini tanpa diimbangi dengan dampak positif lainnya yang berkaitan dengan pemberian layanan oleh panti sehingga proses pemberian pelayanan belum dimunculkan ke permukaan. Penelitian dengan judul "Pelayanan Sosial untuk Balita Terlantar di Panti Yayasan Sayap Ibu (YSI) cabang DIY oleh Arina Fitriana (2013) mengungkapkan lebih banyak isu balita terlantar yang semakin banyak yang menyangkut isu kesejahteraan anak di bidang pekerjaan sosial. Selain itu, standar pelayanan atau proses pelayanan yang digunakan lebih banyak mengacu kepada Standar Nasional Pengasuhan Untuk Lembaga Kesejahteraan Anak dan Peraturan Menteri Sosial Republik Indonesia No. 30 Tahun 2011 tentang Standar Nasional Pengasuhan Anak untuk lembaga Kesejahteraan Sosial Anak, sehingga peneliti sulit untuk menemukan kajian yang bersumber dari teori atau konsep pekerjaan sosial.

Berdasarkan hasil penelitian terkait yang telah diuraikan sebelumnya dan melihat masih terbatasnya penelitian mengenai proses pelayanan sosial berdasarkan konsep pekerja sosial dan mengangkat nilai lebih pada pelayanan sosial yang diberikan oleh lembaga, maka peneliti tertarik untuk meneliti proses pelayanan sosial di Rumah Yatim At-Tamim Bandung dari awal penerimaan santri hingga tahap terminasi.

KAJIAN PUSTAKA
A. Organisasi Pelayanan Sosial (Human Services Organization)

Definisi organisasi pelayanan sosial (human services organization) bermacam-macam. Menurut Hasenfeld (1983) organisasi pelayanan sosial adalah sekumpulan individu yang tergabung dalam suatu organisasi yang fungsi utamanya adalah untuk melindungi, memelihara atau meningkatkan kesejahteraan pribadi individu-individu dengan cara menentukan, menetapkan, merubah atau membentuk ciri-ciri pribadi mereka. Lebih lanjut dalam eksiklopedia pekerjaan sosial, organisasi pelayanan sosial melakukan pelayanan langsung kepada klien. Organisasi pelayanan sosial juga tidak berorientasi kepada keuntungan semata kepada "stakeholders" tetapi tujuannya untuk meningkatkan kesejahteraan orang-orang yang dilayani, sehingga hampir semua organisasi pelayanan sosial adalah lembaga yang bersifat non profit (The Encyclopedia of Social Work, 1995 : 1787). Oleh karena itu, organisasi pelayanan sosial tentunya berbeda dengan organisasi profit lainnya. Adapun karakteristik dari organisasi pelayanan sosial menurut Hasenfeld (1983), yaitu :

1. Material dasarnya (raw material) terdiri dari orang-orang dengan sejumlah nilai moral yang mempengaruhi aktifitas organisasi sosial.

2. Tujuan dari organisasi pelayanan sosial adalah samar-samar (vague), berarti dua (ambiguous), dan bermasalah (problematic).

3. Moral ambigu yang mengitari pelayanan sosial juga menunjukkan organisasi pelayanan sosial bergerak dalam lingkungan bergolak, artinya lingkungan tersebut terdiri dari banyak kepentingan kelompok yang berbeda-beda.

4. Organisasi pelayanan manusia harus beroperasi dengan teknologi yang tidak menentukan dengan tidak menyediakan pengetahuan yang lengkap bagaimana mencari hasil yang diharapkan. 
5. Aktivitas utama dalam organisasi pelayanan sosial terdiri dari hubungan antara staff dengan klien, sehingga tidak menutup kemungkinan para staff dalam organisasi sosial lebih banyak terdiri dari relawan yang harus berhubungan dengan kliennya.

6. Karena keutamaan hubungan staff dengan klien, maka posisi dan peran staff profesional secara khusus penting dalam organisasi pelayanan manusia.

7. Organisasi pelayanan sosial miskin pengukuran mengenai efektivitas yang reliabel dan valid, dan mungkin, lebih mampu bertahan terhadap perubahan dan inovasi ( Dasar-dasar pekerjaan sosial : $85)$.

Pendapat lain mengenai karakteristik organisasi pelayanan manusia dikemukakan oleh Martin (1985 : 2), yaitu the purpose of human service organizations is to meet the socially recognised needs people. Bahwa tujuan organisasi pelayanan sosial adalah memenuhi kebutuhan orang. Selain itu, human service organizations are mandated and resourced by all or a substantial part of the public, through statutory resources or donations, and operate without a profit making purpose yang artinya organisasi pelayanan manusia memperoleh kewenangan dan sumber oleh semua atau sebagian penting masyarakat umum, yaitu sumber-sumber dan donasi menurut undang-undang dan bergerak tanpa tujuan mencari keuntungan.

Dari definisi yang dikemukakan oleh Hasenfeld dan karakteristik mengenai organisasi pelayanan manusia oleh Martin dan Hasenfeld, kita dapat menarik kesimpulan bahwa organisasi pelayanan manusia ini ditujukan untuk memenuhi kebutuhan klien dalam upaya untuk mensejahterakan orang yang dilayani. Organisasi pelayanan manusia ini juga terdiri dari sumber daya manusia yang membentuk sebuah sistem pelayanan yang tidak berorientasi kepada profit atau mencari keuntungan melainkan mengangkat nilai sosial dimana orang yang dilayaninya pun tetap bisa menjalankan keberfungsian sosialnya.

\section{B. Jenis Organisasi Pelayanan Sosial}

Organisasi pelayanan sosial di Indonesia banyak jenisnya dan secara garis besar dapat dikategorikan berdasarkan kegiatan, jenis penanganan, wilayah dan teknologi yang digunakan dalam mengolah sumber daya yang ada dalam oganisasi pelayanan sosial. Organisasi berdasarkan wilayah di bagi menjadi tingkat daerah, nasional dan internasional. Berdasarkan proses penanganannya dibagi berdasarkan kuratif atau penyembuhan, proses dan perubahan. Selanjutnya menurut Yaheskel Hasenfeld (1983 : 4-7) bahwa organisasi pelayanan manusia atau sosial dilihat berdasarkan "materi atau bahan dasarnya" dapat dibagi menjadi 2 dimensi yaitu manusia yang berfungsi normal 'normal functioning' dan yang tidak berfungsi secara normal 'malfunctioning' yang dapat dilihat berdasarkan fisik, psikologis dan sosial. Sedangkan berdasarkan penggunaan teknologi pelayanan yang digunakan ada 3 jenis, yaitu :

1. People processing technologies (pemrosesan manusia), bertujuan untuk memberikan status atau label sosial tertentu kepada klien sehingga dapat ditentukan jenis pelayanan apa yang diperlukan.

2. People suistaining technologies (pemeliharaan manusia), sifatnya lebih kepada mencegah, memelihara dan mempertahankan kesejahteraan klien, tetapi tidak langsung merubah atribut atau perilaku klien.

3. People changing technologies (perubahan manusia), teknologi ini untuk merubah perilaku klien agar dapat meningkatkan kesejahteraannya.

Jenis organisasi pelayanan sosial dalam penerapannya di panti asuhan atau semi panti yaitu lebih kepada penggunaan teknologi 
berbasis people sustaining technologies karena ada sebuah upaya menuju kesejahteraan klien di mana prosesnya tidak instan dalam merubah atribut klien. Hal ini juga tidak terlepas dari fungsi pelayanan yang diberikan kepada klien untuk mencapai kesejahteraan klien.

\section{Fungsi dan Tujuan Pelayanan Sosial}

Menurut Khan, pelayanan sosial memiliki fungsi yang dapat dikelompokkan sebagai berikut :

1. Pelayanan-pelayanan untuk sosialisasi dan pengembangan, misalnya pusat kegiatan untuk anak dan remaja, termasuk kegiatan yang dilaksankaan melalui kelompok atau pekerja sosial dengan kelompok. Pelayanan sosial untuk sosialisasi dan pengembangan bertujuan untuk mengadakan perubahan atau menyempurnakan kegiatan-kegiatan pendidikan, asuhan anak, penanaman nilai, serta pengembangan hubungan sosial. Tujuan kegiatan ini selain unuk sosialisasi dapat juga meningkatkan tujuan dan motivasi, sehingga akan meningkatkan mutu perkembnagan kepribadian termasuk aspek kognitif dan emosional.

2. Pelayanan-pelayanan untuk terapi, pertolongan, rehabilitasi, termasuk perlindungan sosial dan perawatan pengganti, misalnya untuk korban yang mengalami kekerasan dalam keluarga dengan jalan menggunakan kelompok primer untuk memperkuat dan menggantikan fungsifungsi yang tidak lagi mengalami gangguan. Selain bentuk diatas, pelayanan ini juga dapat berupa bantuan sngkat, intensif, dan pribadi sifatnya dalam program perbaikan situasi lingkungan sosial. Tujuan pelayanan ini adalah pemulihan kemampuan pelaksanaan peranan-perananan sosial yang sampai saat ini masih sulit ditemukan.

3. Pelayanan untuk mendapatkan akses, informasi dan nasihat, misalnya rujukan kepada pekerja sosial atau tenaga profesional lain untuk mendapatkan pelayanan tertentu yang dibutuhkan, dapat juga didirikan pusat informasi. Pelayanan ini juga berfungsi untuk menghubungkan seseorang dengan sistem sumber pelayanan sosial yang diperlukan agar lebih mudah diketahui, lebih mudah dijangkau bentuk pelayanan ini dapat berupa lembaga bantuan hukum, pelayanan darurat lewat telepon, lembaga khusus yang menangani keluhan, pendidikan komsumen, pelayanan melalui media sosial, dan lain-lain. (Khan, 1979, hal. 27)

Selanjutnya fungsi pelayanan sosial menurut Richard M. Tittmus yang dikutip oleh Muhidin (1992 : 42) sebagai berikut :

a. Pelayanan-pelayanan atau keuntungankeuntungan yang diciptakan untuk lebih meningkatkan kesejahteraan individu, keuarga kelompok dan masyarakat untuk masa sekarang dan masa yang akan datang.

b. Pelayanan-pelayanan atau keuntungankeuntungan yang diciptakan sebagai suatu investasi yang digunakan untuk mencapai tujuan sosial.

c. Selain itu untuk melindungi masyarakat.

d. Pelayanan ini ditujukan bagi mereka yang tidak mendapatkan pelayanan sosial (misalnya kompensasi kecelakaan industri dan lain-lain).

Berdasarkan uraian sebelumnya dan pendapat dari beberapa ahli, pelayanan sosial ini diberikan secara universal dan ditujukan bagi siapapun yang membutuhkan pertolongan bagi mereka yang mengalami ketelantaran dan diberikan perlidungan melalui lembaga yang terorganisir. Sehingga tujuan yang di dapat selain peningkatan kesejahteraan juga untuk mengembangkan kemampuan klien untuk dapat memecahkan masalah yang dihadapinya dan pelayanan yang diberikan oleh organisasi 
untuk meningkatkan keberfungsian sosial klien.

D. Organisasi Pelayanan Manusia Berbasis Agama atau Faith Based Organization

Organisasi pelayanan manusia berbasis agama atau Faith Based Organization memiliki definisi yang beragam, dan istilah ini bukan istilah yang didefinisikan secara hukum, tetapi sering digunakan untuk merujuk kepada organisasi keagamaan dan organisasi amal lainnya yang mempunyai filosofi keagamaan, sehingga terlihat bergitu kental dalam visi dan misi yang ingin dicapai organisasi tesebut. Organisasi pelayanan sosial berbasis agama Islam ini memiliki hukum yang berdasarkan Al-Qur'an dan sunnah Rasul. Filosofi derma yang diwajibkan bagi setiap muslim utamanya dalam memelihara dan menyantuni anak yatim dan menolong bagi mereka yang membutuhkan. Terlebih dalam bidang pendidikan yang merupakan pondasi penting dalam melahirkan generasi bangsa yang berkualitas. Pertimbangan utama dalam faith based organization ini pun tidak terlepas dari bagaimana identitas yang dipilih akan mempengaruhi donor, penyandang dana, pendukung, penerima manfaat yang ditargetkan dan pemangku kepentingan lainnya.

Menurut Indra Bastian dalam buku yang berjudul Akuntansi untuk LSM dan Partai Politik terdapat karakteristik dan lingkungan organisasi keagamaan yaitu secara etimologis "organisasi keagamaan" dapat diartikan sebagai organisasi yang fokusgerakannya terkait dengan basis agama yang dipegang teguh ajarannya sehingga kegiatannya pun berfokus pada bidang keagamaan. Tujuan organisasi keagamaan adalah memberikan pelayanan dan menyelenggarakan seluruh aktivitas yang dibutuhkan maupun yang telah menjadi ketentuan dari lembaga tersebut. Meskipun tujuan utamanya adalah memberikan pelayanan kepada ummat, namun tidak berarti organisasi atau lembaga yang berbasis agama sama sekali tidak memiliki tujuan keuangan, hal ini tergantung pada kondisi ummat yang dilayani. Secara otomatis pula, keuangan menjadi salah satu faktor yang mempengaruhi perkembangan pelayanan dan perlu digaris bawahi bahwa tujuan keuangan organisasi keagamaan ini berbeda secara filosofis, konseptual dan operasional dengan organisasi profit swasta.

Dari definisi di atas, ada beberapa hal pokok yaitu organisasi berbasis keagamaan ini didasarkan pada keyakinan bahwa mereka memiliki kewajiban agama untuk membantu orang miskin dan kurang beruntung dan mereka berdasarkan pada kitab suci mereka, begitu pula dengan organisasi yang berdasarkan agama Islam termasuk dalam pelayanan sosial yang diberikan.

\section{E. Permasalahan dalam Human Service Organization}

Di dalam sebuah organisasi pelayanan manusia, kerap kali terdapat permasalahan baik yang berhubungan dengan administratif maupun non administratif, diantaranya adalah organisasi pelayanan sosial yang masih berkembang memiliki kelemahan dalam perencanaan hal ini juga berhubungan dengan visi misi dan tujuan organisasi yang masih belum jelas. Keadaan ini membuat tidak sedikit organisasi yang dapat tetap suistainable dan berkembang. Permasalahan lainnya adalah seringkali konflik nilai dan harapan terjadi diantara anggota kelompok, tentunya ini dapat menjadi masalah internal bagi organisasi pelayanan manusia. Namun yang perlu diperhatikan organisasi sosial cenderung fokus kepada cara pelayanan sosialnya bukan kepada tujuan secara spesifik dalam jangka waktu baik pendek maupun panjang, sehingga sedikit sulit ketika kita ingin mengukur hasil-hasil dari badan pelayanan sosial dan permasalahan yang terakhir adalah hubungan antara efektivitas badan sosial dan alokasi sumber sering kali mendapat kesulitan.

Menurut Edi Suharto (1997) terdapat karakteristik dan permasalahan organisasi 
pelayanan sosial di Indonesia yang tercantum dalam tabel sebagai berikut :

Tabel 1. Karakteristik dan Permasalahan Organisasi Pelayanan Sosial

\begin{tabular}{|l|l|l|}
\hline No. & Karakteristik & Permasalahan \\
\hline 1. & $\begin{array}{l}\text { Orientasi bukan untuk menari laba } \\
\text { atau keuntungan }\end{array}$ & $\begin{array}{l}\text { Permasalahan finansial, kekurangan } \\
\text { dana karena organisasi pelayanan } \\
\text { sosial juga bergantung pada donasi } \\
\text { dari luar. }\end{array}$ \\
\hline 2. & $\begin{array}{l}\text { Produk dari organisasi pelayanan } \\
\text { sosial bukan barang, tetapi } \\
\text { pelayanan sosialnya }\end{array}$ & $\begin{array}{l}\text { Masih belum mampu memenuhi } \\
\text { kebutuhan anggota dan masyarakat } \\
\text { secara optimal. }\end{array}$ \\
\hline 3. & $\begin{array}{l}\text { Para pengurus bekerja atas dasar } \\
\text { suka rela dan berjiwa relawan }\end{array}$ & $\begin{array}{l}\text { Motivasi dan unjuk kerja pengurus } \\
\text { dalam melaksanakan tugas masih } \\
\text { rendah. }\end{array}$ \\
\hline 4. & $\begin{array}{l}\text { Tidak memiliki indikator atau } \\
\text { kriteria keberhasilan pelayanan } \\
\text { yang jelas }\end{array}$ & $\begin{array}{l}\text { Sulit mengukur pengaruh atau } \\
\text { dampak pelayanan. Masyarakat dan } \\
\text { lembaga donor kurang percaya dalam } \\
\text { memberikan dukungan finansial. }\end{array}$ \\
\hline
\end{tabular}

Sumber :Wibhawa, Budhi, dkk. 2010. Dasar-dasar Pekerjaan Sosial,hal.122

\section{F. Pelayanan Sosial Bagi Anak}

Pengertian pelayanan sosial bermacammacam, menurut Departemen Sosial, pelayanan sosial adalah suatu kegiatan yang dilakukan secara profesional untuk membantu memecahkan permasalahan sosial yang dialami oleh individu, keluarga, kelompok dan masyarakat dengan menggunakan pendekatan praktik pekerjaan sosial. Definisi pelayanan sosial secara umum dikemukakan oleh Zastrow (1985:8) yaitu "the social work profession exist to provide human and effective social services to individuals, families, group, communities, and society so that social functional may be enhanced and the quality of live emproved".

Pengertian pelayanan sosial dapat dilihat dalam arti luas dan sempit. Dalam arti yang lebih luas dinyatakan oleh Khan :

Social services may be interpreted in an institutional context as consisting of programs made available by orther than market criteria to assure a basic level of helath education, welfare provision, to enhance communal living and individual functioning, to facilitate access to services and institutions generally, and to assist those in difficulty and need (p.179).

Sedangkan dalam arti sempit, pelayanan sosial mencakup program pertolongan dan perlindungan kepada golongan yang tidak beruntung seperti pelayanan sosial bagi anak terlantar, keluarga miskin, cacat, tuna sosial dan sebagainya (Muhidin, 1992:41). Lebih lanjut Spicker (1995), seorang penulis Inggris menyatakan bahwa pelayanan sosial meliputi jaminan sosial, perumahan, kesehatan, pekerjaan sosial, dan pendidikan. Dari definisi di atas, kita dapat melihat bahwa bentuk pelayanan sosial ini diberikan sebagai solusi dalam memecahkan masalah bagi anak terlantar maupun bagi mereka yang memiliki keterbatasan dalam bidang ekonomi yang perlu untuk kita berikan bantuan dan pertolongan. Salah satu bentuk pelayanan sosial adalah 
program pendidikan yang dapat dilakukan oleh lembaga pelayanan sosial.

Kriteria pemberian pelayanan sosial ini bukan semata-mata berdasarkan kemampuan orang untuk membayar, melainkan pemberian pelayanan sosial ini didasarkan atas kebutuhan, sehingga walaupun tidak mampu untuk membayar, tetap akan diberikan pelayanan sesuai yang dibutuhkan. Idealnya, pelayanan pendidkan, kesehatan dan perumahan jaminan sosial, pelatihan kerja disediakan pada tingkat minimal untuk meningkatkan kehidupan masyarakat dan keberfungsian sosial orang-orang.

Pekerja sosial dengan anak merupakan sebuah pelayanan yang dilakukan untuk membantu anak dalam meningkatkan keberfungsian sosialnya, termasuk anak di dalam panti asuhan. Pekerja sosial juga berperan dalam upaya peningkatan kemampuan anak dalam memenuhi kebutuhan hidupnya, mampu menjalankan peran dan statusnya sesuai dengan tahap perkembangannya dan mampu menyelesaikan masalah yang sedang dihadapinya.
Dalam penelitian ini pelayanan sosial dilakukan bagi anak dan remaja yang diasuh di Rumah Yatim At-Tamim Bandung. Menurut Alfred J.Khan dalam Soetarso (1993) menjelaskan tujuan pelayanan sosial bagi anak merupakan salah satu usaha dalam meningkatkan kesejahteraan anak, keluarga maupun orang-orang yang mengalami kesulitan baik di bidang kesehatan, pendidikan dan perumahan.

Lebih lanjut Edi Suharto (1997:363) mengemukakan tujuan pelayanan sosial bagi anak yaitu agar anak dapat tumbuh kembang secara optimal maka kebutuhan dasar anak harus terpenuhi, meliputi kebutuhan fisiologis, kasih sayang, pendidikan, kesehatan, perlindungan serta kesempatan yang menyangkut dirinya. Sehingga dari apa yang diungkapkan oleh Edi Suharto kita dapat menarik kesimpulan bahwa pemenuhan kebutuhan dasar anak dapat mempengaruhi tumbuh kembang anak. Adapun model holistik-komprehensif pelayanan kesejahteraan sosial bagi anak, sebagai berikut

Tabel 2. Model Holistik-Komprehensif Pelayanan Kesejahteraan Sosial Bagi Anak

\begin{tabular}{|l|l|l|}
\hline \multicolumn{1}{|c|}{$\begin{array}{c}\text { Pendekatan dan } \\
\text { Sasaran }\end{array}$} & \multicolumn{1}{|c|}{ Strategi } & \multicolumn{1}{c|}{ Program } \\
\hline Individual ; anak & $\begin{array}{l}\text { Child Based Services } \\
\text { Institutional Based } \\
\text { Services }\end{array}$ & $\begin{array}{l}\text { Konseling, perawatan medis, } \\
\text { rehabilitasi sosial, pemisahan } \\
\text { sementara atau permanen }\end{array}$ \\
\hline $\begin{array}{l}\text { Kelompok : keluarga } \\
\text { inti dan keluarga besar }\end{array}$ & Family Based services & $\begin{array}{l}\text { Konseling keluarga dan } \\
\text { perkawinan, terapi kelompok, } \\
\text { program lainnya }\end{array}$ \\
\hline $\begin{array}{l}\text { Masyarakat : komunitas } \\
\text { lokal }\end{array}$ & $\begin{array}{l}\text { Community Based } \\
\text { services } \\
\text { Location } \\
\text { Services } \\
\text { Hlaf Way Home Based } \\
\text { Services }\end{array}$ & $\begin{array}{l}\text { Pengembangan masyarakat, } \\
\text { terapi sosial, kampanye sosial, } \\
\text { aksi sosial, rumah singgah, } \\
\text { rumah belajar }\end{array}$ \\
\hline Negara : pemerintah & $\begin{array}{l}\text { State Based Services } \\
\text { serumusan kebijakan, law } \\
\text { enforcement }\end{array}$ \\
\hline
\end{tabular}

Sumber : Edi Suharto, halaman 373

Berdasarkan model tersebut, maka terdapat 7 strategi pelayanan sosial bagi anak, yaitu :
1. Child Based Services. Strategi ini menempatkan anak sebagai basis penerima pelayanan sosial. Anak yang 
mengalami luka fisik maupun psikis segera diberika pertolongan yang bersifat krisis, baik perawatan medis, konseling atau dalam keadaan tertentu anak diamankan sementara dari kehidupan keluarga yang beresiko.

2. Institutional Based Services. Anak yang mengalami masalah ditempatkan dalam lembaga pelayanan sosial atau panti. Pelayanan sosial yang diberikan meliputi, fasilitas tinggal menetap, pemenuhan kebutuhan dasar, perlindungan, pendidikan dan pelatihan keterampilan, serta program rehabilitasi sosial lainnya.

3. Family Based Services. Keluarga dijadikan sasaran dan medium utama pelayanan yang diarahkan kepada pembentukan dan pembinaan keluarga agar memiliki kemampuan ekonomi, psikologis dan sosial dalam menumbuh kembangkan anak, sehingga mampu memecahkan masalahnya sendiri dan menolak pengaruh negatif yang merugikan dan membahayakan. Keluarga sebagai satu kesatuan diperkuat secara utuh dan harmonis dalam memebuhi kebutuhan anak. Misalnya program usaha ekonomi produktif diterapkan pada keluarga yang memiliki masalah keuangan.

4. Community Based Services. Strategi yang menggunakan masyarakat sebagai pusat penanganan ini bertujuan untuk meningkatkan kesadaran dan tanggung jawab masyarakat agar ikut aktif dalam menangani permasalahan anak. Peran pekerja sosial datang secara periodik ke masyarakat untuk merancang dan melaksanakan program pengembangan masyarakat, bimbingan dan penyuluhan, terapi sosial, kampanye sosial, aksi sosial, serta penyediaan sarana rekreatif dan pengisian waktu luang.

5. Location Based Services. Pelayanan ini diberikan di lokasi anak yang mengalami masalah, strategi ini biasanya diterapkan pada anak jalanan, anak yang bekerja di jalan dan pekerja anak. Para pekerja sosial mendatangi pabrik atau tempat dimana anak berada, dan memanfaatkan saran ayang berada disekitarnya sebagai fasilitas media perolongan.untuk anak jalanan dan anak yang bekerja di jalan, strategi ini sering disebut sebagai Street Based Services (pelayanan berbasiskan jalanan), (Fery Johannes, 1996).

6. Half Way House Services. Strategi ini disebut juga strategi semi panti yang lebih terbuka dan tidak kaku, strategi ini dapat berupa rumah singgah, rumah terbuka untuk berbagai aktivitas, rumah belajar, rumah pengganti keluarga, dan lain sebagainya.

7. State Based Services. Pelayanan dalam strategi ini bersifat makro dan tidak langsung (macro and indirect services). Para pekerja sosial mengusahakan situasi dan kondisi yang kondusif bagi terselenggaranya usaha kesejahteraan sosial bagi anak. Perumusan kebijakan kesejahteraan sosial dan perangkat hukum bagi perlindungan anak merupakan bentuk program dalam strategi ini. (Edi Suharto, pembangunan kebijakan sosial dan pembangunan sosial, 374-375).

\section{G. Tahapan Pelayanan Sosial}

Tahapan pelayanan sosial ini dilakukan di rumah yatim berbasis panti. Secara etimologi , panti sosial berarti rumah, tempat (kediaman) yang diberlakukan untuk kemasyarakatan. Secara konseptual dapat dikemukakan bahwa panti sosial adalah suatu lembaga kesejahteraan yang bertanggung jawab untuk memberikan pelayanan sosial kepada mereka yang membutuhkan.

Berikut ini merupakan hasil kesimpulan dari beberapa ahli yaitu Max Siporin, .E. Benjamin dan Edna Naito Chan (2006 : 431) dan Ipul Suharma (Buku Saku Pekerja Sosial, 2004 : 3) bahwa dalam kegiatan pelayanan sosial, terdapat beberapa tahapan, yaitu : 
1. Tahapan pendekatan awal,tahapan ini merupakan proses kegiatan awal yang dapat meliputi konsultasi dengan pihak terkait, sosialisasi program pelayanan, pemberian motivasi, seleksi, perumusan kesepakata dan penempatan calon penerima pelayananan serta identifikasi saraan dan pra sarana pelayanan.

2. Pengungkapan dan pemahaman masalah (assessment) adalah suatu proses kegiatan dan analisis data untuk mengungkpakan dan memahami masalah, kebutuhan dan sistem sumber klien.

3. Perencanaan pemecahan masalah (planning) adalah suatu proses perumusan tujuan dan kegiatan pemecnahan masalah, serta penetapan berbagai sumber daya (manusia, biaya, metode, teknik, saran dan pra sarana, serta waktu yang dibutuhkan untuk mencapai tujuan tersebut).

4. Pelaksanaan pemecahan masalah (intervention) yaitu suatu proses penerapan rencana pemecahan masalah yan tela dirumuskan. Kegiatan pemecahan masalah yang dilaksanakan adalah melakukan pemelihaaan, pemberian motivasi dan pendampingan kepada penerima pelayanan dalam bimbingan dan bimbingan pembinaan lanjutan.

a. Bimbingan yaitu suatu proses kegiatan pelayanan yang diberikan kepada klien untuk membuhi kebutuhan mental, fisik dan psikis klien. Bimbingan ini terdairi dari fisik, keterampilan, psikososial, sosial, pengembangan masyarakat dan advokasi.

b. Bimbingan dan pembinaan lanjutan adalah suatu prose spemberdayaan dan pengembangan agar penerima pelayanan sosial dapat melaksanakan tugas-tugas kehidupan dan fnungsi sosialnya.

5. Monitoring

6. Evaluasi, terminasi dan rujukan a. Evaluasi adalah suatu proses kegiatan untuk mengetahui efektifitas dan efisiensi pencapaian tujuan pemecahan masalah dan atau indikator-indikator keberhasilan pemecahan masalah.

b. Terminasi adalah suatu proes kegiatan pemutusan hubungan pelayanan atau pertolongan antara lembaga dan penerima pelayanan (klien).

c. Rujukan adalah suatu kegiatan merancang, melaksanakan, mensupervisi, mengevaluasi dan menyusun laporan kegiatan rujukan penerima program pelayanan kesejahteraan sosial.

H. Jenis Pelayanan Sosial Berbasis Panti

Sukoco (Kemitraan dalam Pelayanan Sosial, h.106-107) lebih lanjut memaparkan jenis pelayanan berbasis panti sebagai berikut :

1. Pelayanan pengasramaan, yaitu memberikan tempat tinggal sementara kepada klien

2. Pelayanan pemenuhan kebutuhan pangan yaitu pemberian makan dan minu sebagai kebutuhan primer dengan berbagai menu yang ditetapkan agar gizi anak asuh terpnuhi.

3. Pelayanan konseling, yaitu pelayanan dalam bentuk bimbimbingan untuk meningkatkan kemauan dan kemampuan berinteraksi dengan orang lain, menjalankan peran sosial, memenuhi kebutuhan dan memecahkan masalah.

4. Pelayanan kesehatan yaitu pelayanan pengontrolan dan pengecekan kesehatan klien secara rutin oleh tenaga medis agar diketahui tingkat kesehatan klien.

5. Pelayanan pendidikan yaitu pelayanan pemberian kesempatakan klien baik secara formal maupun informal. 
6. Pelayanan keterampilan yaitu pelayanan bimbingan keterampilan kerja, keterampilan menjalankan aplikasi komputer atau berwirausaha.

7. Pelayanan bimbingan mental adalah pelayanan dalam bidang agama dengan menjalankan aktifitas kegamaan atau ceramah.

8. Pelayanan rekreasi dan hiburan yaiu pelayanan yang ditujukan untuk memberikan rasa gembira dan senang mealui bentuk permainan, musik, media, dan kunjungan ke tempat rekreasi.

Namun tidak semua jenis pelayanan diatas dapat dilakukan sepenuhnya oleh lembaga pelayanan sosial dikarenakan keterbatasan finasnsial dan faktor lainnya.

\section{Kebutuhan Dasar Anak}

Setiap anak memiliki kebutuhan dasar yang harus terpenuhi, tidak terkecuali bagi anak yang berada di panti asuhan atau rumah yatim. Sebelum kita mengetahui kebutuhan dasar anak, berikut ini akan dipaparkan kebutuhan dasar manusia terlebih dahulu menurut Maslow dalam Goble (1987) :

1. Kebutuhan fisiologis; Kebutuhan ini pada umumnya bersifat untuk menjaga agar unsur-unsur fisik dapat seimbang (neostatik). Seperti halnya asupan makanan, minuman, protein, nutrisi dan gizi yang dibutuhkan oleh tubuh, kebutuhan akan istirahat, seks, dan lainlain.

2. Kebutuhan akan rasa aman

3. Kebutuhan akan pemberian kasih sayang

4. Kebutuhan akan penghargaan

5. Kebutuhan akan aktualisasi diri

Setelah kita mengetahui kebutuhan dasar manusia, berikut ini merupakan kebutuhan dasar yang dimiliki oleh anak. Menurut Titi (1993) yang dikutip oleh Soetjiningsih (1995:14) menjelaskan bahwa terdapat beberapa kebutuhan anak untuk dapat tumbuh dan berkembang yang secara umum dapat digolongkan menjadi tiga kebutuhan dasar, yaitu :

\section{Kebutuhan fisik-biomedis (“ASUH”)}

Kebutuhan ini meliputi kebutuhan sandang, pangan yang memenuhi asupan gizi dalam kebutuhan, tempat tinggal yang layak, perawatan kebutuhan dasar, perawatan kesehatan (termasuk pengobatan jika sakit), kebutuhan bermain, rekreasi dan lain-lain.

2. Kebutuhan emosi atau kasih sayang (“ASIH")

Kebutuhan emosi ini perlu untuk dipenuhi bagi anak, karena pada dasarnya ada sebuah kelekatan dan kasih sayang yang seharusnya diberikan oleh pihak keluarga namun kini digantikan oleh pihak panti. Selain itu, hal ini juga dapat mempengaruhi tumbuh kembang anak baik bagi perkembangan fisik, mental dan psikososialnya. Bentuk kasih sayang orang tua atau pengganti orang tua ini akan membangun kepercayaan dasar (basic trust) sang anak.

3. Kebutuhan akan stimulasi mental ("ASAH")

Kebutuhan ini menyangkut stimulasi mental yang merupakan cikal bakal dalam pendidika dan pelatihan pada anak. Stimulasi mental ini juga dapat mengembangkan perkembangan mental psikososial yang antara lain meliputi kecerdasan, keterampilan, kemandirian, kreativitas, agama,kepribadian, moral dan etika, dan lain-lain.

\section{J. Peran Pekerjaan Sosial}

Pekerja sosial adalah salah satu profesi profesional yang turut andil dan memiliki peranan yang penting dalam pemberian pelayanan sosial khususnya yang diberikan oleh lembaga pelayanan sosial. Pekerjaan sosial menurut Charles Zatrow dalam Dewi 
Heru Sukoco (1991 : 7-8) merupakan suatu profesionalisme yang bekerja membantu individu, keluarga, komunitas dan masyarakat agar dapat berdaya untuk meringankan, mengurangi, memecahkan, dan menyelesaikan masalah yang dihadapinya dan mewujudkan keberfungsian sosial mereka sesuai dengan peranannya.

Hal ini mengingat pekerja sosial berada pada setting human service organization yang identik dengan pelayanan sosial khususnya bagi anak yatim, dhuafa dan mereka yang membutuhkan. Maka bentuk pelayanan sosial yang diberikan akan sesuai dengan kebutuhan klien di lapangan. Pekerja sosial dapat memberikan layanan sosial setelah melakukan assessment dengan klien dan pihak keluarga klien yang bersangkutan. Pekerja sosial juga bekerja dalam memberikan pelayanan sosial di Rumah Yatim yang berbasis half way house services (pelayanan semi panti), dimulai dari tahap assessment hingga terminasi kepada anak yatim, dhuafa maupun muallaf di Rumah Yatim.

Pekerja sosial di Indonesia yang concern bekerja di panti masih minim, hal ini dikarenakan kurangnya sosialisasi dan jaminan dalam meniti karir, salah satu alasannya adalah masalah finansial. Pertimbangan ini didasarkan kepada profesionalisme yang menandakan kita bekerja dan dibayar, akan tetapi hal ini menjadi pengecualian ketika kita memiliki jiwa sosial yang tinggi. Selain itu, volunteer kebanyakan ikut bergabung pada lembaga pelayanan sosial khususnya yang sudah berkembang pesat. Keprihatinan ini masih berkembang seiring dengan kondisi rumah yatim atau panti asuhan yang berada di kabupaten bahkan pelosok daerah.

Pekerja sosial dalam praktiknya melihat bahwa isu pelayanan ini bukan saja menjadi pekerjaan rumah bagi sebagian orang, melainkan tanggung jawab bagi semua pihak. Salah satu caranya dapat diperjuangkan melalui pembuatan kebijakan untuk memperjuangkan kesejahteraan anak khususnya bagi anak asuh di Panti asuhan atau rumah yatim lainnya dan memberikan saran agar dapat meningkatkan pelayanan sosial bagi panti atau rumah yatim terkait. Selain itu, pekerja sosial dapat memberikan akses dalam melanjutkan pendidikan formal bagi anak asuh di Rumah Yatim At-Tamim. Peran lainnya adalah memberikan konseling dan juga pemberian pengasuhan yang dibutuhkan. Tentunya hal ini tidak terlepas dai nilai-nilai pekerja sosial yaitu acceptance, nonjudgmental,individualisasi, self determinatin, genuine, conrol emotional,confidentiality.

\section{KESIMPULAN}

Rumah Yatim At-Tamim merupakan salah satu organisasi pelayanan sosial yang berbasis agama Islam dan memberikan pelayanan dalam bentuk pengasramaan, pemenuhan kebutuhan sehari-hari, pendidikan baik formal dan informal yang bebasis nilai agama Islam dan saat ini memberikan layanan sosial kepada anak yatim, dhuafa dan muallaf yang membutuhkan bantuan. Adapun proses pelayanan di Rumah Yatim At-Tamim berdasarkan intisari dan persamaan beberapa ahli sebagai berikut :

1. Tahapan pendekatan awal, tahapan ini merupakan proses kegiatan awal yang dapat meliputi konsultasi dengan pihak terkait, sosialisasi program pelayanan, pemberian motivasi, seleksi, perumusan kesepakata dan penempatan calon penerima pelayananan serta identifikasi saraan dan pra sarana pelayanan.

2. Pengungkapan dan pemahaman masalah (assessment) adalah suatu proses kegiatan dan analisis data untuk mengungkpakan dan memahami masalah, kebutuhan dan sistem sumber klien.

3. Perencanaan pemecahan masalah (planning) adalah suatu proses perumusan tujuan dan kegiatan pemecnahan masalah, serta penetapan berbagai sumber daya (manusia, biaya, metode, teknik, saran dan pra sarana, serta waktu yang dibutuhkan untuk mencapai tujuan tersebut). 
4. Pelaksanaan pemecahan masalah (intervention) yaitu suatu proses penerapan rencana pemecahan masalah yan tela dirumuskan. Kegiatan pemecahan masalah yang dilaksanakan adalah melakukan pemelihaaan, pemberian motivasi dan pendampingan kepada penerima pelayanan dalam bimbingan dan bimbingan pembinaan lanjutan.

a. Bimbingan yaitu suatu proses kegiatan pelayanan yang diberikan kepada klien untuk membuhi kebutuhan mental, fisik dan psikis klien. Bimbingan ini terdairi dari fisik, keterampilan, psikososial, sosial, pengembangan masyarakat dan advokasi.

b. Bimbingan dan pembinaan lanjutan adalah suatu prose spemberdayaan dan pengembangan agar penerima pelayanan sosial dapat melaksanakan tugas-tugas kehidupan dan fnungsi sosialnya.

5. Monitoring

6. Evaluasi, terminasi dan rujukan

a. Evaluasi adalah suatu proses kegiatan untuk mengetahui efektifitas dan efisiensi pencapaian tujuan pemecahan masalah dan atau indikatorindikator keberhasilan pemecahan masalah.

b. Terminasi adalah suatu proes kegiatan pemutusan hubungan pelayanan atau pertolongan antara lembaga dan penerima pelayanan (klien).

c. Rujukan adalah suatu kegiatan merancang, melaksanakan, mensupervisi, mengevaluasi dan menyusun laporan kegiatan rujukan penerima program pelayanan kesejahteraan sosial.
Jika proses pemberian pelayanan sosial ini dapat berjalan dengn baik, maka pemenuhan kebutuhan anak akan terpenuhi dan anak asuh di Rumah Yatim At-Tamim dapat menjalankan keberfungsian sosialnya dengan baik.

\section{DAFTAR PUSTAKA}

Adi, Rukmanto, Isbandi. 1994. Psikologi, Pekerjaan Sosial dan Ilmu Kesejahteraan Sosial Dasar-Dasar Pemikiran. Pt Raja Grafindo Persada : Jakarta

Fahrudin, Adi. 2012.Pengantar Kesejahteraan Sosial. Bandung: PT. Refika Aditama

Hurlock,B.Elizabeth. 1980. Psikologi Perkembangan Edisi ke 5. I Jakarta : Erlangga

Hurlock,B.Elizabeth. 1980. Psikologi Perkembangan Edisi ke 5. I Jakarta : Erlangga

Jones, Andrew . 1995. Working in Human Services Organization, a Critical Introduction. Australia : Longman.

Kettner, Daley \& Nichols. 1995. Iniziating Change in Organizations and Communities. California : Brooks/Cole Publishing Company

Kamus Besar Bahasa Indonesia W.J.S. Poerwadarminta, Kamus Umum Bahasa Indonesia

Nuryanti, Lusi. 2008. Psikologi Anak. Jakarta : Indeks

Suharto, Edi. 2006. Membangun Masyarakat Memberdayakan Rakyat Kajian Strategi Pembangunan Kesejahteraan Sosial dan Pekerjaan Sosial. Bandung: PT. Refika Aditama

Suharto, Edi. 2004. Pembangunan, Kebijakan Sosial dan Pekerjaan Sosial. Bandung: PT. Refika Aditama

Suharto, Edi. 2011. Kebijakan Sosial Sebagai Kebijakan Publik. Bandung : Alfabeta 
Sahara, H. dan Jamal Lisman H. 1992. Pengantar Pendidikan 1, Jakarta: PT Gramedia Widia Sarana

Sihombing, U. 2002. Pendidikan Berbasis Masyarakat. Jakarta: CV Multiguna

Wibhawa Budhi, T.Raharjo, Santoso \& B. Meilany. 2010. Dasar- Dasar Pekerjaan Sosial Pengantar Profesi Pekerjaan Sosial. Widya Padjadjaran.

Zastrow, Charles. 1995. The Practice of Social Work. 4th Edition. California : Brooks/Cole Publishing Company.

Data Dinas Sosial, antarajawabarat.com/lihat cetak/25056 2012

Skripsi oleh Rossy Simarmata dengan judul Efektivitas Pelayanan Sosial Terhadap Anak Asuh oleh Yayasan Kinderfreude, Ilmu Kesejahteraan Sosial Univesitas Sumatera Utara

Artikel oleh Hariana, 2013 dengan judul Penerapan Pengukuran Kualitas Pelayanan di Lembaga Kursus Keterampilan "X" Kota Gorontalo

Artikel oleh Dodi Setiadi Lase, 2009 dengan judul Efektivitas Pelayanan Sosial Anak di Bidang Pendidikan oleh Panti Asuhan Al-Washliyah Kelurahan Gedung Johor Kecamatan Medan Johor

Jurnal psikologi Islam (JPI) Copright 2011 Lembaga Penelitian dan Pengembangan Psikologi Keislman (LP3K). Vol 8 No.2,
Januari 2011 231-246. Oleh Ayu Nuzulia Rahma. Psikologi Gajah Mada. Hubungan Efikasi Diri dan Dukungan Sosial dengan Penyesuaian Diri Remaja di Panti Asuhan, dengan Subjek Remaja Usia 13-17 Tahun di Panti Asuhan Darul Hadlonah Kota Semarang

Artikel Karolina Lamtiur Dalimunthe. 2009. "Kondisi Psikososial Anak yang Dibesarkan di Panti Asuhan". Universitas Padjadjaran.

Skripsi oleh Arina Fitriana (2013) dengan judul "Pelayanan Sosial untuk Balita Terlantar di Panti Yayasan Sayap Ibu (YSI) cabang DIY". Ilmu Kesejahteraan Sosial. UIN Sunan Kalijaga Yogyakarta.

http://simbi.kemenag.go.id/pustaka/images/m ateribuku/Data\%20Panti\%20Asuhan\%2 0Yatim\%20Piatu_2011.pdf

http://www.bandungkab.go.id/uploads/DATA _YAYASAN_KESBANG.pdf

https://www.academia.edu/5262375/Defining FaithBased_Organizations_and_Understandi ng Them_Through_Research

http://www.bandungkab.go.id/uploads/DATA _YAYASAN_KESBANG.pdf

http://www.bps.go.id/linkTabelStatis/View/id/ 1488 